\title{
Obstetric delivery in mechanically ventilated critically ill pregnant women
}

\author{
SE Lapinsky ${ }^{1,2^{*}}$, JA Rojas-Suarez ${ }^{3,4}$, TM Crozier ${ }^{5}$, DN Vasquez ${ }^{6}$, N Barrett ${ }^{7}$, G Bourjeily ${ }^{8,9}$ \\ From ESICM LIVES 2015 \\ Berlin, Germany. 3-7 October 2015
}

\begin{abstract}
Introduction
Approximately 1 in 500 pregnancies develop complications requiring mechanical ventilatory support, the majority of episodes occurring postpartum. While uncommon, the situation of a pregnant woman requiring ventilatory support for respiratory failure is very concerning. Delivery of the fetus is often considered, either to improve maternal well-being or due to concerns for the fetus. Little data exist to guide physicians in these decisions.
\end{abstract}

\section{Objectives}

To evaluate the effect of obstetric delivery on maternal respiratory function, in pregnant women ventilated for respiratory failure.

\section{Methods}

Subgroup analysis of a retrospective review of pregnant women from 4 ICUs in 4 countries over a 10 year period, who received mechanical ventilation for greater than 24 hours. In women who delivered while on mechanical ventilation, maternal respiratory parameters were evaluated pre-delivery and 2-5 hours and 12-15 hours postdelivery. Respiratory system compliance was estimated from recorded ventilator plateau pressure and tidal volume. Data are presented as median and interquartile ratio (IQR).

\section{Results}

We identified nine women who delivered while ventilated for respiratory failure. Median age was 29 (22.5-33.5) years and gestation 29 (27.5-31) weeks. Pre-delivery Pa02/Fi02 ratio was 268 (131-317) and $\mathrm{PaC0} 37.3$ (33.2-49) $\mathrm{mmHg}$. Duration of ventilation prior to delivery was $1.5(1-2)$ days, and time from delivery to extubation was 2 (1-3.8) days. All deliveries were by Cesarean section except one

${ }^{1}$ Mount Sinai Hospital, Toronto, Canada

Full list of author information is available at the end of the article spontaneous stillborn delivery at 26 weeks. Cesarean sections were performed for either maternal respiratory indications $(\mathrm{n}=3)$ or for obstetric/fetal indications $(\mathrm{n}=5)$. APGAR scores at 1 minute were low $(\leq 7)$ in all 8 elective deliveries, and only 3 recovered to $>7$ by 5 minutes. All mothers survived, as did all but one neonate (the spontaneous delivery).

Delivery had a variable effect on maternal respiratory parameters. By 12-15 hours, oxygenation index had improved from a median 7.5 (5.9-16.2) to 6 (4.9-9.1), and PEEP was reduced from $11 \mathrm{cmH}_{2} \mathrm{O}(8.5-12)$ to $9 \mathrm{cmH}_{2} \mathrm{O}$ (6.5-10). Estimated compliance improved in most patients, but to a variable degree. Three hypercapnic patients (mean $\mathrm{C} 0257 \mathrm{mmHg}$ ) improved, to mean $\mathrm{PaC0} 2$ of $46 \mathrm{mmHg}$.

\section{Conclusions}

This relatively small case series examines a rare but important intervention in the ICU - delivery of the fetus in a pregnant woman ventilated for respiratory failure. Delivery occurred early in the mothers' ventilator course, followed by extubation within a few days in the majority of patients. The effect of delivery on maternal respiratory function was variable, with some, but not all women showing an improvement in oxygenation and respiratory system compliance. At delivery, fetal compromise was evident but all neonates survived to hospital discharge.

\section{Authors' details}

${ }^{1}$ Mount Sinai Hospital, Toronto, Canada. ${ }^{2}$ University of Toronto, Interdepartmental Division of Critical Care Medicine, Toronto, Canada.

${ }^{3}$ Gestion Salud Clinic, Intensive Care Unit, Cartagena, Colombia. ${ }^{4}$ Universidad de Cartagena, Grupo de Investigación en Cuidados Intensivos y Obstetricia, Cartagena, Colombia. ${ }^{5}$ Monash Medical Centre, Intensive Care Unit, Clayton, Australia. ${ }^{6}$ Sanatorio Anchorena, Buenos Aires, Argentina. ${ }^{7}$ Monash Medical Centre, Department of Obstetrics \& Gynaecology, Clayton, Australia. ${ }^{8}$ Warren Alpert Medical School of Brown University, Pulmonary and Critical Care Medicine, Providence, Rl, United States. ${ }^{9}$ The Miriam Hospital, Providence, Rl, United States.

\section{SpringerOpen ${ }^{\circ}$}

(C) 2015 Lapinsky et al.; This is an Open Access article distributed under the terms of the Creative Commons Attribution License (http:// creativecommons.org/licenses/by/4.0), which permits unrestricted use, distribution, and reproduction in any medium, provided the original work is properly cited. 
doi:10.1186/2197-425X-3-S1-A275

Cite this article as: Lapinsky et al:: Obstetric delivery in mechanically ventilated critically ill pregnant women. Intensive Care Medicine Experimental 2015 3(Suppl 1):A275.

\section{Submit your manuscript to a SpringerOpen ${ }^{\circ}$ journal and benefit from:}

- Convenient online submission

- Rigorous peer review

- Immediate publication on acceptance

- Open access: articles freely available online

- High visibility within the field

- Retaining the copyright to your article

Submit your next manuscript at $\gg$ springeropen.com 